\title{
The Effects of Oil Production and Ethnic Representation on Violent Conflict in Nigeria: A Mixed-Methods Approach
}

\author{
CARLO KOOS
}

GIGA German Institute of Global and Area Studies, Institute of African Affairs, Hamburg, Germany

\section{JAN PIERSKALLA}

Department of Political Science, The Ohio State University, Columbus, Ohio, USA

\begin{abstract}
A large qualitative literature on violent conflict in Nigeria has identified the importance of oil production and ethnicity as salient factors in understanding violence, especially in the oil rich Niger Delta. This resonates with the broader literature on natural resources, ethnic exclusion, and conflict. This article advances existing research by providing the first highly disaggregated statistical analysis of oil, ethnicity, and violence for Nigerian Local Government Areas (LGAs). We test whether oil production in a weak state environment, and local groups' access to governmental power, affect the level of violence in Nigeria. We employ unique disaggregated data on violent conflict events, proprietary data on oil production, and newly collected information on local ethnic groups' access to the federal govern ment for 774 LGAs. We find strong evidence that LGAs with oil infrastructure experience significantly more violence than others, while access to the federal government significantly reduces violence. We complement these findings with a qualitative investigation of violent conflicts in Nigeria.
\end{abstract}

Keywords ethnic exclusion, mixed methods, natural resources, Nigeria, oil, violence

\section{Introduction}

Two arguments have been frequently used to explain violent domestic conflicts in various contexts. Building on the established grievance literature, some have argued that political exclusion of ethnic groups results in political violence. ${ }^{1}$ Others have emphasized the importance of natural resources, especially oil, for inciting violence. ${ }^{2}$ Both arguments feature mechanisms that can be situated more broadly in the distinction

Carlo Koos is affiliated with the GIGA German Institute of Global and Area Studies, Institute of African Affairs. Jan Pierskalla is an Assistant Professor in the Department of Political Science at The Ohio State University.

Address correspondence to Jan Pierskalla, Department of Political Science, The Ohio State University, 154 N. Oval Mall, Columbus, OH 43210, USA. E mail: pierskalla.4@, osu.edu 
between motives (e.g., grievances) that provoke organized violence ${ }^{3}$ and structural opportunities that incentivize or disincentivize violence. ${ }^{4}$ Although both arguments have been tested in cross-country studies, there still exists disagreement about the existence of effects, scope conditions, and the underlying causal mechanisms.

This study enriches the existing debate by assessing the effects of both oil and political exclusion-related mechanisms on a more disaggregated level. We test both arguments using the case of Nigeria, which is well suited for such an analysis for at least three reasons. First, Nigeria's federal structure of 36 states and 774 Local Government Areas (LGAs) provides a useful set of comparable geographic units to conduct a rigorous test of both arguments. Second, Nigeria features structural conditions (e.g., weak institutions, oil infrastructure, and rents) that invite resource-related violence. Third, the level of political representation varies highly across ethnic groups. A large number of ethnic groups are politically and economically marginalized, which should then taking the grievance argument seriously be associated with a higher risk of engaging in political violence. Assessing both mechanisms simultaneously is important. For one, political marginalization of ethnic groups can be due to the state's desire to monopolize access to resource rents; violence related to oil extraction can be equally intertwined with ethnic politics. Hence, identifying the role of oil and political exclusion of ethnic groups in creating the potential for violence in the presence of each other should offer useful additional insights for the current debate.

Scholarship on political violence in Nigeria puts a strong focus on the political economy of oil and the political, economic, and ecological deprivation of local minorities. However, research is almost exclusively dominated by qualitative studies. ${ }^{5}$ One reason for that is the high cost of gathering systematic data in Nigeria. Most studies agree that the expanding oil industry brought along elite competition for oil rents, environmental pollution, and expropriation; and subsequently nurtured local feelings of exploitation by the state and the oil companies. Initially peaceful protests in the 1990s addressing these grievances were repressed by the state. This state behavior contributed to a radicalization of local protest movements and led to the high-profile conflict that afflicted the area in the 2000s. ${ }^{6}$

Yet what these studies lack is the ability to tell us whether the claim that oil endowments fuel violence holds more broadly across oil-producing areas. Similarly, qualitative work on the political grievances and violent collective action of ethnic groups, such as the Ijaw tribe in the Niger Delta, lacks a broader comparative component. Existing studies are not designed to test these arguments. Given the limitations of the existing literature, we suggest that a mixed-methods approach integrating a quantitative and qualitative analysis can extend our knowledge in that regard.

Our main statistical analysis exploits cross-sectional variation in the total amount of violence between 2006 and 2012 in all 774 LGAs $^{7}$ in Nigeria to disentangle the effects of oil production and ethnic exclusion. This analysis draws on new and fine-grained violent events data for Nigeria and has the advantage of taking the spatial variation of oil production and political representation into account, not only between states, but also within states. We also implement a series of additional tests. For example, we use alternative but coarser data on violent events with better time coverage to construct a panel of LGAs from 2001 to 2010 to test the robustness of our findings. We complement the quantitative analysis with qualitative evidence that allows us to flesh out the logic of the proposed causal mechanisms. The quantitative analysis shows that LGAs with more oil production suffer from more violence. Also, 
including representatives of ethnic groups at the national level has a pacifying effect. Qualitative accounts and field research support the arguments in general, but also show their limitations.

Overall, our analysis supports the existing arguments on oil-related violence and political inclusion. We conclude that both natural resources and the political status of ethnic groups matter for understanding broad patterns of violence in Nigeria, but local dynamics have to be taken seriously in order to understand violence above and beyond coarse structural factors.

\section{Natural Resources and Political Grievances in the Civil War Literature}

\section{Natural Resources and Conflict: Weak States, Motives, and Opportunities}

Previous research has conceptualized three major mechanisms regarding how valuable natural resources contribute to political violence. ${ }^{8}$

First, natural resources can have a rather indirect, enabling effect on armed conflicts through what Le Billon dubs the "resource curse." "This suggests that a state's dependence on resource rents negatively affects socio-economic development and political institutions. This is the case when governments receive revenues from resource rents and do not depend on their citizens' taxes. In turn, the state citizen relationship suffers and tends to make governments act less accountably, which, by extension, negatively affects the quality of policies and provision of public goods. ${ }^{10}$ Such conditions may not directly promote violence, but provide a fertile ground on which grievances can grow.

Second, natural resources can promote violence by providing a direct motive. The process of resource extraction is often associated with negative externalities, such as environmental degradation, the destruction of livelihoods, eviction of local communities, and the militarization of resource assets. ${ }^{11}$ Perceptions of unfair compensation and re-distribution provide particularly strong motives. Such grievances can inform strong narratives to legitimize insurgent campaigns.

The third causal mechanism of how resources may affect violent conflict is by providing structural and financial opportunities to rebels, or what Ross refers to as a "looting" mechanism. ${ }^{12}$ Motives are important to mobilize followers, but they are not sufficient to financially launch and maintain a rebellion. Access to lootable resources and extraction infrastructure can provide funds for rebels and valuable targets for military action, regardless of a motive. ${ }^{13}$

These three outlined mechanisms are not mutually exclusive. They can work in concert and reinforce each other. For instance, the weakening of state institutions can foster the emergence of grievances and rapacious warlords and thus provide the conditions for the other two mechanisms to function.

Earlier cross-country studies find that oil endowments affect civil war onset. ${ }^{14}$ Some subsequent studies use geo-referenced data to show that oil has an effect on the duration of civil wars. ${ }^{15}$ A couple of studies suggest that oil makes secessionist conflicts in particular more likely ${ }^{16}$ and that very low and very high levels of oil revenues per capita are associated with less violence. ${ }^{17}$ More recent work that utilizes exogenous variation in oil wealth finds no evidence for any conflict-increasing effects of oil. ${ }^{18}$ In sum, while there exists some evidence that natural resources, in particular oil, are associated with violent conflict, exact scope conditions and underlying mechanisms need to be further investigated. ${ }^{19}$ 


\section{Grievances, Ethnic Identity, and Political Violence}

Gurr's relative deprivation theory suggests that group inequality leads to frustration because of a gap between what people believe they should deserve and what they actually get. ${ }^{20}$ Grievances provide strong grounds for mobilization when linked with salient ethnic identities.

Ethnic identity is a prime source of intra-group cohesion and consequently under certain conditions of inter-group fighting. ${ }^{21}$ Shared ethnic bonds produce strong relationships, foster mutual expectations within groups, and facilitate social control of members. Such shared characteristics facilitate collective action. ${ }^{22}$

Taken together, a shared ethnic identity provides a sound basis for political entrepreneurs to frame and alter political objectives as collective grievances. Entrepreneurs can create narratives that amalgamate grievances and feelings of ethnic identity. Such narratives can be very powerful tools to mobilize ethnic communities.

Recent empirical work consistently shows that horizontal inequalities and political exclusion are associated with higher risks of civil wars. ${ }^{23}$ Drawing on a dataset that codes the political status of ethnic groups over time, Cederman et al. find that countries face higher risks of violence when relevant ethnic groups are politically excluded. $^{24}$

\section{Formulating Our Hypotheses}

We believe that both the arguments about oil resources and the political exclusion of ethnic groups can be fruitfully subjected to empirical testing in the Nigerian context. What are the observable implications of each strand of argument for the geography of violence in Nigeria?

The causal mechanisms of how oil endowments can affect political violence have been outlined above. We discussed the resource curse, the motive, and the opportunity mechanisms. What are the quantitatively measureable implications of these three causal mechanisms? First, we abstain from deriving a testable hypothesis for the resource curse, simply because in our within-country analysis there is no variation on these country-level features. ${ }^{25}$ Then, both motive and opportunity mechanisms will depend on physical materializations such as oil wells, pipelines, oil spills, and oil company buildings. The geographic location of essential oil infrastructure ought to be an important correlate of violence across Nigerian localities. Therefore, the first hypothesis shall expect a positive relationship between physical oil production sites and violent events. If oil production provides a motive and opportunities to rebels, there should be a positive relationship with the occurrence of violent events: ${ }^{26}$

\section{Hypothesis 1 (H1): Oil production increases the likelihood of violent conflict.}

The second mechanism to be tested is whether the political representation of a local ethnic group is associated with political violence. Drawing on Cederman et al., we assume that groups which are politically represented are less likely to rebel. ${ }^{27}$ Political representation by itself might address fundamental grievances of prior excluded groups. In addition, having co-ethnics in political office can force the allocation of state resources and development initiatives to be directed to the 
represented group. High-level representatives can also effectively liaise with the state and their respective populace, making policies addressing a group's demands more credible. Moreover, the symbolic and emotional value of political representation will contribute to a stronger identification of the populace with the state.

We do not believe that political representatives will ultimately and exclusively pursue their populace's interests and demands. For example, they may or may not be coopted by a regime, engage in private rent-seeking, or simply have little influence in relieving the grievances of their ethnic group. Yet, even with these possible limitations, representation at the national level should have a pacifying effect as it serves as a symbolic victory and allows access to financial resources and the possibility to distribute these within one's group:

H2: Ethnic representation decreases the likelihood of violent conflict.

\section{Research Design}

In order to disentangle the role of oil and political exclusion in political violence, it is important to consider both factors simultaneously in a comparable context. While some studies focus on natural resources and others on the effects of ethnic exclusion, we believe it is crucial to consider the potential interrelatedness between the mechanisms. The presence of natural resources (and appropriation of associated fiscal revenues) can intensify local ethnic identity and contribute to the sense of political marginalization of local groups. Similarly, the presence of developed and activated ethnic identities in areas of natural resource extraction can facilitate the mobilization of collective resistance against the state or rival groups.

Accordingly, testing the usefulness of each argument in the Nigerian subnational context is promising. First, Nigeria provides appropriate scope conditions (e.g., weak institutional legitimacy and capacity, oil rents, widespread poverty) to test the arguments. And second, Nigeria features political violence that has been associated in the literature with varying degrees of both oil exploitation and ethnic politics, providing a rich empirical setting to disentangle both effects.

In order to test the theoretical claims, we employ a mixed-methods approach relying on both quantitative and qualitative evidence. ${ }^{28}$ Using both methods allows us to exploit the strengths of both methods, while compensating for their weaknesses. The statistical analysis will test the two proposed hypotheses and look at the broader patterns. We complement these findings with a qualitative test where our focus remains with the more detailed causal mechanisms. In sum, we can provide a substantive test of the theoretical claims.

\section{Quantitative Analysis}

\section{Data and Model}

To test our theoretical claims about the extraction of oil and the access of local groups to political representation, we construct a spatially disaggregated data set for all 774 Nigerian LGAs. Our specific unit of analysis is the individual LGA. Taking the whole of Nigeria as our sample and not just, for example, the nine Niger Delta states, allows us to contrast the importance of oil production and the political marginalization of ethnic groups for understanding violence in all Nigerian regions. For our main 
analysis we focus on cross-sectional variation in our data, instead of also modeling changes over time. This is largely due to data limitations for our dependent and independent variables, which are available for limited time frames, or are either time invariant or only slowly changing.

Our main dependent variable is an aggregate conflict event count for each LGA for the 2006 to 2012 time period. We compute violent event counts based on a database maintained by Nigeria Watch, a Non-Governmental Organization (NGO) that collects detailed, geo-coded information on events with at least one death for all of Nigeria, starting in $2006 .{ }^{29}$ The event data by Nigeria Watch is based on 15 local daily and weekly newspapers as well as reports by human rights organizations. This data source contains far better geographic coverage than either Uppsala Conflict Data Program's Georeferenced Event Dataset (UCDP-GED) or Armed Conflict Location \& Event Data (ACLED), which are commonly used in the quantitative literature. This data source contains 6746 events with at least one casualty. As an alternative to the event counts, we also calculate total aggregate casualties for each LGA in the same time period. ${ }^{30}$

Figure 1 shows the spatial distribution of events across Nigerian LGAs in the 20062012 time period, binned into $20 \%$ quantiles.

First, note that our event data capture broader trends identified in the discourse on violence in Nigeria: Violence seems to cluster in the Niger Delta, the Middle Belt, and the Northeast. Our data also show, though, that the distribution of violent events is highly skewed. Sixty percent of all LGAs experienced less than four violent events in the 20062012 time period, $80 \%$ less than 10. At the same time the top 20th percentile of LGAs host over $70 \%$ of all conflict events recorded by Nigeria Watch. The distribution of casualties shows a similar, even stronger skew. This illustrates that violence in Nigeria is an incredibly concentrated and local phenomenon.

Our main independent variables focus on the extraction of oil and the political inclusion of ethnic groups. To identify the production sites of oil, we rely on geo-referenced data on oil fields. We obtained proprietary data on oil fields from GIS Solutions Nigeria, a firm providing geo-referenced data on oil fields, gas flares, pipelines, and oil wells. Based on this information we generate a simple count of oil fields for each LGA. This data offers more detailed information on oil exploitation in Nigeria than PETRODATA, ${ }^{31}$ which has been used commonly in the literature. As an alternative measure, we also exploit information on the density of the local pipeline network. Pipelines are also of practical importance because of violence

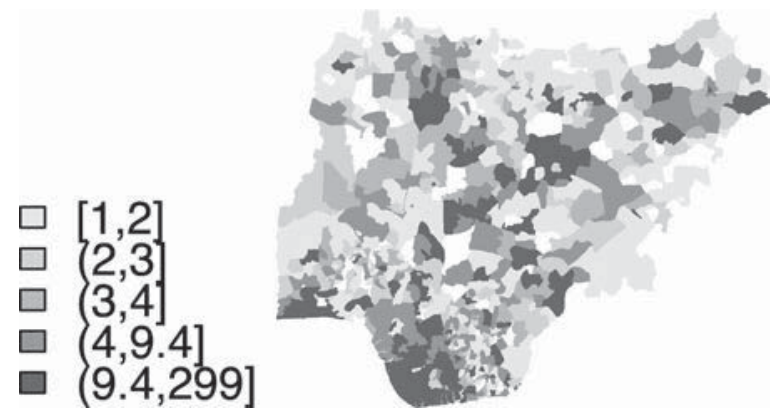

Figure 1. Violent events in Nigeria, 2006 2012. Numbers indicate number of event counts binned into $20 \%$ quantiles. 
related to large-scale oil theft (also known as "bunkering") and the fact that pipelines run through territories further removed from oil extraction sites. A narrow focus on oil fields might miss important physical loci of conflict that provide potentially easier access for local groups to oil rents. Our data come from GIS Solutions Nigeria and we calculate the length of the pipeline network per square kilometer for each LGA. ${ }^{32}$

To capture the political inclusion and exclusion of local ethnic groups, we collected new data on the ethnic composition of the federal cabinet and the settlement areas of Nigeria's main ethnic groups. To determine settlement areas, we used information from Nigeria's Statistical Office, which provides detailed maps on the geographic areas populated by specific ethnic groups. In these maps the statistical office distinguishes between more than 50 ethnic identities. To simplify measurement, we adopted Rainer and Trebbi's categorization of 17 ethnic groups, which capture the major linguistic groups in Nigeria. ${ }^{33}$ For each LGA, we identified the local ethnic groups living in the area. We then proceeded to code the ethnic identity of all Nigerian federal cabinets from 1999 to 2012, using two independent expert teams with profound knowledge of Nigerian politics (see details in the Appendix, which is available online please see "Supplemental" section below for details). Based on this combined information, we determined the share each local group has in the national cabinet and added shares of groups within the same LGA; then we averaged the LGA share for the pre-2006 time period. This variable represents the degree of political inclusion of local groups at the national level. Note that this measure effectively combines information from the national level with information on local ethnic groups and captures the degree to which the local population has linkages to the federal executive.

In that regard, Nigeria has adopted and institutionalized the principle of the "federal character" in its constitution, which aims to foster national unity and equity among Nigerian ethnic groups and states. Various provisions such as minimum quota and representation patterns for the population have been made to substantiate this concept in the federal government, the armed forces, and other government agencies. With regard to the federal government composition, these provisions include, for instance, that the elected president shall appoint at least one minister from each state of the federation. If the available positions are too few though, then distribution shall be done according to the six geopolitical zones. ${ }^{34}$ While such mechanisms appear relatively straightforward on paper, they are profoundly complex in practice because they need to consider federal, zonal, state, and local government identities and interests. Critics argue that these constitutional provisions on the composition of ministerial and presidential appointments have been quite ineffective in reducing actual and perceived dominance by a few ethnic groups. Hence, the chances of ethnic minorities such as the Ijaw, Ogoni, and many others whose role will be discussed in the qualitative section to attain positions in the federal government remained relatively low in the past. ${ }^{35}$

To parse-out the effects of our two main variables of interest, we include a number of control variables in our analysis. We draw largely on information provided in the 2006 Nigerian population census. We control for (logged) population counts and size of the LGA, since more populous and larger areas are more likely to experience violent events. To control for potential effects of ethnic fractionalization, we include the number of ethnic groups living in each LGA. ${ }^{36}$ To account for the effects of local development levels, we add to our models the percentage of the population with access to electricity, the share of the population that owns a residence, and the share of the population squatting. To measure the difficulty of the terrain, we calculate the share of the LGA covered by deep forests. 
Since we are interested in the effects of oil on violent collective action, we have to address the possibility that the central government uses fiscal revenue to buy off the support of the local population. To account for such effects, we use data on yearly fiscal allocations from the federal government to the LGAs. The Office of the Accountant General, a control institution within the Nigerian Ministry of Finance, provides a publication of fiscal allocations from the federal government, respectively the federation account, to all states and LGAs between 1999 and 2008 on a monthly basis. ${ }^{37}$ However, various sources suggested that these figures may not arrive at the respective local government councils and even if they do, these funds are not necessarily invested into the provision of public goods. ${ }^{38}$ There exist no reliable records on what amounts actually make it to the local governments, and it is largely the discretion of the state governors to distribute these resources. Given this, it is difficult to form clear expectations about the effect of fiscal allocations on violence, or how its inclusion affects any omitted variable bias with regard to our two main variables. We therefore only include this measure in an additional robustness check. Based on the yearly fiscal flows, we calculate the average per capita allocation in the 20002006 time period. This ensures that we measure the effect of prior fiscal allocations on ensuing levels of violence, avoiding any direct reverse causality problems. Summary statistics for all variables can be found in the Appendix (available online).

Since our main dependent variable is a count of events or casualties, we rely on standard negative binomial count models to statistically estimate the effects of oil production and ethnic inclusion on the intensity of violence. Using a negative binomial model is important to account for the clear over-dispersion in the event counts. We cluster standard errors at the state level to account for arbitrary serial correlation and heteroskedasticity.

\section{Results}

Table 1 shows our main results. Model (1) shows our baseline estimates with the number of events as dependent variable. Of the control variables, only four reach standard levels of statistical significance. Unsurprisingly, higher logged population counts are associated with more violent events. Among the socioeconomic variables, higher electricity access in the population also is associated with more conflict, while a higher rate of home ownership is found in LGAs with less violence. The electrification result might be due to empowerment effects of socioeconomic development. While at the cross-country level economic development reduces incidence of political violence, the same is not necessarily true for within-country variation. LGAs with more forested areas also have, on average, fewer violent events.

More importantly, moving to our two main variables of interest, we find that the number of oil fields is positively associated with conflict, statistically significant below the $1 \%$ level. This finding is in line with our theoretical expectations and lends support to the general idea that oil extraction provides motives and opportunities for violent collective action. Counteracting this conflict-increasing factor, we find that higher rates of political inclusion of local ethnic groups in the national government reduce violent conflicts. The coefficient for ethnic inclusion is negative and statistically significant below the $0.1 \%$ level. This finding suggests that political representation can be a powerful force in mitigating conflictual competition for resource revenues. 


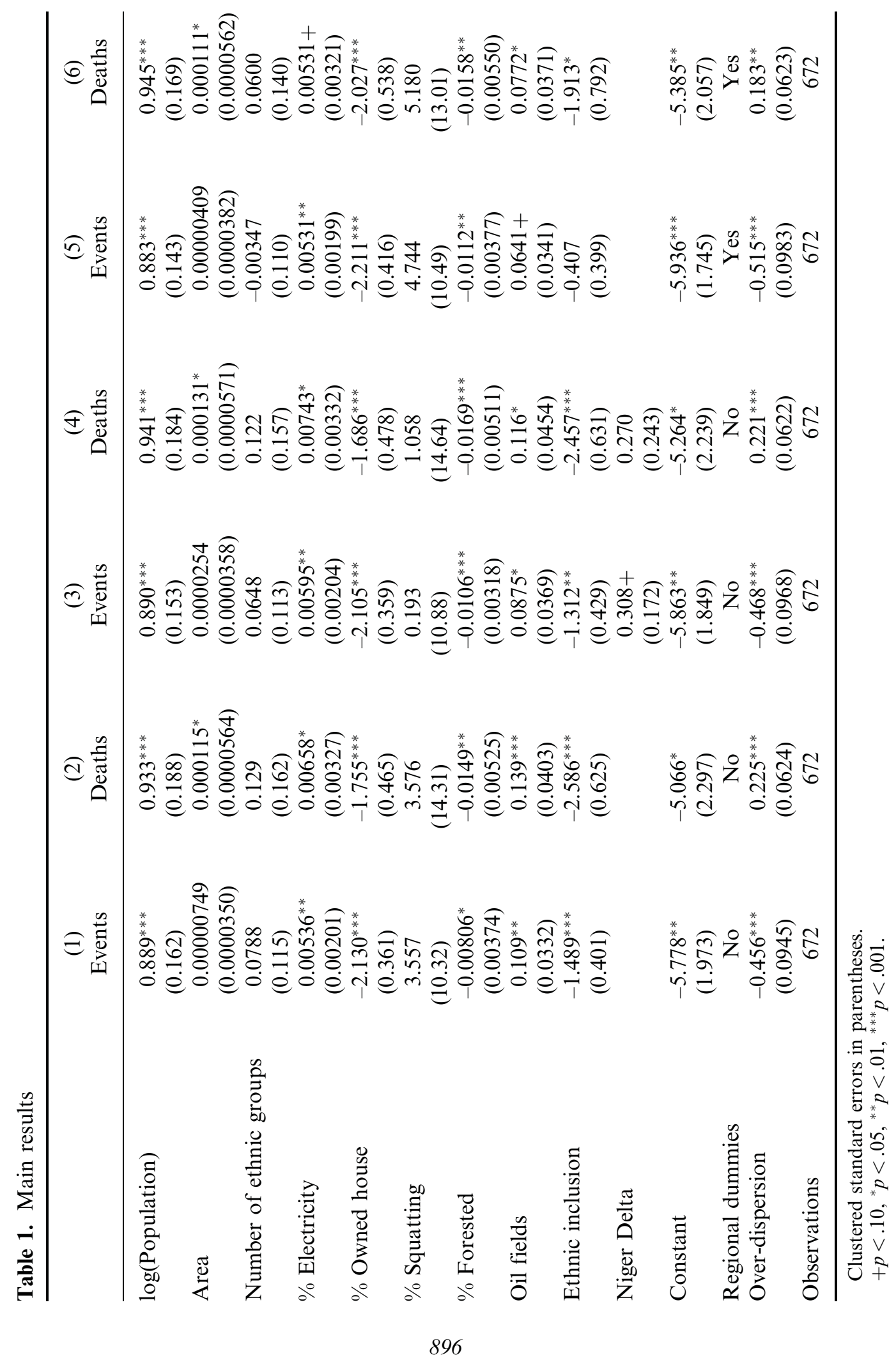


Model (2) in Table 1 re-estimates the same model, now with the number of casualties as dependent variable. Again, we find strong support for our two hypotheses. For our next robustness check we add as an additional control a dummy variable for LGAs located in the Niger Delta. Again, we estimate models for event counts, Model (3), and casualty counts, Model (4). As can be seen, our main results are completely robust to controlling for idiosyncratic characteristics of the Niger Delta. While the Niger Delta dummy itself is positive, it fails to reach the standard threshold of 5\% in terms of statistical significance. In Models (5) and (6) we replace the Niger Delta dummy with a complete set of regional dummies. ${ }^{39}$ While this somewhat weakens the statistical significance of the oil field and ethnic inclusion estimate, we still find overall very robust support for the conflictual nature of oil production and the pacifying effects of political inclusion of ethnic groups. Importantly, our findings with regard to the presence of oil infrastructure are not specific to oilfields, but apply equally to other forms of extraction infrastructure. Specifically, as a robustness check we re-estimate the models in Table 1 using the length of the pipeline network per square kilometer as an alternative measure. We still find that oil infrastructure is associated with higher levels of violence and casualties, providing further empirical support to the importance of large-scale oil theft for violence in Nigeria (see Appendix, available online, for detailed results). Another potential indicator for the presence of oil infrastructure is the occurrence of gas flares. We use data on gas flares from GIS Solutions Nigeria and also re-estimate the models from Table 1, confirming our prior finding measured by oil fields, pipelines, or gas flares the production side of the oil industry is positively associated with a larger number of violent events in Nigerian LGAs over the 20062012 time period. Moreover, our results are robust to controlling for fiscal allocations per capita. While LGAs with higher fiscal allocations experience more conflict, it does not change our two findings with regard to oil production or ethnic inclusion. The positive association between violence and fiscal allocations might exist because the government sends more money to hotspots of violent collective action to engender political support in the long run, or because local groups engage in violent competition to appropriate government rents, or because of a discrepancy between official allocations and actual realization of fiscal flows.

None of our findings are driven by the choice of estimator. We find largely similar results for a Poisson regression model or simple OLS with logged event counts as dependent variable. ${ }^{40}$

Apart from statistical significance, our results also are substantively meaningful. We simulated the implied change in the number of expected event counts when increasing each of our two main variables from their mean by two standard deviations. ${ }^{41}$ For the oil field variable, the expected increase in event counts is approximately 2.54 events, while better ethnic representation reduces event counts by 2.2 events, on average. Given that the median event count for an LGA is three events, these indicate the importance of oil and ethnic politics for understanding violence in Nigeria.

To further investigate possible differences between the Niger Delta and the rest of Nigeria, we also provide estimates for separate models. Table 2 shows in Model (1) one set of results for the Niger Delta only and in Model (2) for the rest of Nigeria. For LGAs in the Niger Delta we still find that the number of oil fields are associated with higher levels of conflict. In other words, even within the Niger Delta region, it is especially localities that host oil installations and are slated to receive the most 
Table 2. Results by region

\begin{tabular}{|c|c|c|}
\hline & $\begin{array}{c}(1) \\
\text { Niger Delta }\end{array}$ & $\begin{array}{c}(2) \\
\text { Non Niger Delta }\end{array}$ \\
\hline $\log ($ Population $)$ & $\begin{array}{l}0.761^{* *} \\
(0.265)\end{array}$ & $\begin{array}{l}0.982^{* * *} \\
(0.125)\end{array}$ \\
\hline Area & $\begin{array}{r}0.0000931 \\
(0.000178)\end{array}$ & $\begin{array}{c}0.0000179 \\
(0.0000364)\end{array}$ \\
\hline Number of ethnic groups & $\begin{array}{c}0.443+ \\
(0.241)\end{array}$ & $\begin{array}{c}0.229^{*} \\
(0.0906)\end{array}$ \\
\hline$\%$ Electricity & $\begin{array}{c}0.00411+ \\
(0.00227)\end{array}$ & $\begin{array}{l}0.00739^{* *} \\
(0.00243)\end{array}$ \\
\hline$\%$ Owned house & $\begin{array}{l}2.123^{* * *} \\
(0.463)\end{array}$ & $\begin{array}{l}1.965^{* * *} \\
(0.421)\end{array}$ \\
\hline$\%$ Squatting & $\begin{array}{c}21.13^{* * *} \\
(6.365)\end{array}$ & $\begin{array}{r}9.774 \\
(12.31)\end{array}$ \\
\hline$\%$ Forested & $\begin{array}{c}0.00607 \\
(0.00571)\end{array}$ & $\begin{array}{c}0.0127^{* * *} \\
(0.00288)\end{array}$ \\
\hline Oil fields & $\begin{array}{l}0.0823+ \\
(0.0452)\end{array}$ & \\
\hline Ethnic inclusion & $\begin{array}{c}0.545 \\
(1.769)\end{array}$ & $\begin{array}{l}1.589^{* * *} \\
(0.434)\end{array}$ \\
\hline Constant & $\begin{array}{c}4.103 \\
(2.935)\end{array}$ & $\begin{array}{l}7.162^{* * *} \\
(1.507)\end{array}$ \\
\hline Over-dispersion & $\begin{array}{c}0.446^{*} \\
(0.208)\end{array}$ & $\begin{array}{l}0.551^{* * *} \\
(0.0993)\end{array}$ \\
\hline Observations & 172 & 500 \\
\hline
\end{tabular}

Clustered standard errors in parentheses.

$+p<.10,{ }^{*} p<.05,{ }^{* *} p<.01,{ }^{* * *} p<.001$.

revenue per capita that are experiencing the highest levels of conflict. For the Niger Delta LGAs, we find that the degree of ethnic representation at the national level has no statistically significant effect on violence. Note that this only signifies that variation in political representation between Niger Delta LGAs does not explain patterns of violence largely because there is little variation within the region. ${ }^{42}$ The results do not speak to the importance of ethnic political inclusion for the region as a whole. When we turn to the remaining regions of Nigeria, we again find evidence in line with our theoretical expectations. We find that more extensive representation at the national level leads to lower event counts.

This set of additional findings is important, because it shows that, while there is a clear relevance of oil for the Niger Delta as a whole, it also explains variation in violence within the Niger Delta region. Moreover, it seems that the politics of ethnic representation are very important for understanding patterns of violence across regions of Nigeria.

Since our main measures of interest as well as several control variables are either time invariant, slow changing, or simply not available on a yearly basis, our main analysis relies on cross-sectional variation in the total amount of violence from 
2006 to 2012. Ideally, we would like to exploit geographic as well as temporal variation in violence to test the two hypotheses, but data limitations make this challenging. In the absence of better data, we nonetheless construct a panel of LGAs from 2001 to 2010 as a robustness check. Doing so requires stronger assumptions about several variables. Since the Nigeria Watch data only start in 2006, we rely for this analysis on data from ACLED ${ }^{43}$ and UCDP-GED ${ }^{44}$ to identify the number of conflict events in each LGA-year. Our measure of oil production enters as a time-invariant variable, whereas our measure of ethnic inclusion does reflect how changes in cabinet compositions affect the representation of local ethnic groups in each year. We include as time-invariant factors the same set of control variables as in the main analysis, simply assuming that information provided by the 2006 census is roughly representative for the 20012010 time period. To control for dynamics and time shocks, we also include year fixed effects. As before, we estimate negative binomial models with the ACLED and UCDP-GED event counts as dependent variables. We successively add a control for the Niger Delta and regional dummies to account for unobserved effects. Again, this analysis strongly confirms our main findings. Across nearly all models both our measure of oil production and ethnic inclusion have the expected signs and are statistically significant at conventional levels (see Appendix, available online, for details).

Even when disaggregating the data along a temporal dimension, we find clear evidence that both oil production and ethnic inclusion are important factors in understanding political violence in Nigeria.

\section{Qualitative Evidence}

This section seeks to complement our statistical analysis in testing the explanatory power and the limits of our theoretical framework. Our approach here is what George and Bennett dub a "disciplined configurative case study," suited to test and refine the discussed causal mechanisms. ${ }^{45}$ Therefore, the causal mechanisms discipline the remainder of this section. We start by discussing the "resource curse" and the scope conditions it produces in Nigeria. We continue with the oil-related motive and opportunity mechanism. Here, we put a natural focus on the Niger Delta, simply because the necessary conditions are restricted to oil production. With regard to the argument about political representation, we will also reflect on the Middle Belt and Northern Nigeria. Although the current political affairs are historic legacies, we focus the analysis mainly due to space restriction on the period from the mid-1990s up to today.

\section{Resource Curse and the Political Economy of Oil: The Scope Conditions for Violent Conflict}

It was stated that natural resources can have an indirect effect on political violence. Governments dependent on fiscal rents (e.g., oil) tend to produce weak state institutions and socio-economic policies, which provide fertile conditions for political violence to emerge.

Nigeria is a prime example of a weak state not in terms of its military capacity, but with regard to its institutions and its dedication to development. Oil contributes $85 \%$ to government revenues and $90 \%$ to export income. ${ }^{46}$ This constant flow of oil revenues dwarfs tax-generated income and has produced a political economy that 
revolves around oil rents instead of the needs of the Nigerian population. This system has incentivized opportunistic rent-seeking behavior among the country's political and economic elite. This has certainly contributed to a deterioration of relations between the state and the average citizen. The state citizens relationship has been described as highly dysfunctional mainly because of the "cargo mentality" (you take as much as you can as long as you can) and "state capture" by the ruling elites. $^{47}$

While a small circle of Nigerians benefit from the current state of affairs, the majority of Nigerians have experienced little improvement of their living conditions over the last decades. ${ }^{48}$ In general, the level of public services provision is low. Nigeria's human development index is even below the average of sub-Sahara Africa. ${ }^{49}$

The dissatisfaction among Nigerians about the Nigerian state is widespread. Blackouts are common even in the metropolitan cities Abuja, Lagos, and Port Harcourt, and more so in the rural areas. It is common to have public electricity for not more than six hours per day. The National Electric Power Authority (NEPA) is commonly referred to as "Never Expect Power Always." 50 Fuel shortages are a common phenomenon at Nigerian gas stations. These circumstances owe to the fact that Nigerian governments have abandoned existing refineries in order to maintain the lucrative business arrangements where fuel has been reimported to Nigeria from foreign refineries. ${ }^{51}$

There are numerous examples of how state governments mismanage and embezzle funds in construction projects, fuel subsidies, health care, and education.

Probably one of the most pressing problems is the absence of employment for young men. Not only unskilled laborers face difficulties in finding jobs, but also university graduates. The lack of opportunities in the formal job market makes thousands of them vulnerable to drift into criminal careers. Among Nigerians this is often referred to with the proverb that "the devil makes work for idle hands." State-level politicians, warlords, local cult movements, and terrorist groups do recruit from this pool of unemployed youth. Particularly in the run-up to elections, armed youth groups have been used to intimidate the local population, fight political competitors, and rig the ballot. $^{52}$

While oil production itself is not responsible for political violence, it allows the Nigerian state to retain its modest performance. Poor governance, corruption, poverty, and unemployment have fueled collective discontent and have provided fruitful conditions for social and political conflict.

\section{Resource Control as Motive to Rebel}

The second suggested causal mechanism of how natural resources can attribute to political violence is by providing a motive to rebel.

While the political elite enjoyed a steady stream of oil revenues, local communities in the Niger Delta ${ }^{53}$ began to feel alienated by being excluded from the economic benefits while being left with the ecological burden of the booming oil industry. ${ }^{54}$ In the early 1990s, a combination of economic, environmental, and political deprivation led to the rise of local initially non-violent protest movements such as the Movement for the Survival of the Ogoni People (MOSOP) and later the Ijaw Youth Council (IYC), which demanded that local grievances be addressed. Given the government's dependence on a functioning oil production in the region, the prime goal 
was to retain a level of public order that did not affect oil production. While one possibility for the government would have been to engage in an open dialogue about addressing grievances, hardliners made the Nigerian state react to these non-violent movements with violent repression. ${ }^{55}$ While the protests were crushed by the army, the resentments of the local population and in particular of the youth intensified. ${ }^{56}$

Although Nigeria returned to democratic rule in 1999, the way in which grievances in the Niger Delta were managed by the federal and state governments hardly improved. With the increase of the derivation to oil-producing states, the Niger Delta state governments experienced a considerable increase of allocated oil revenues from 2000 onwards and belonged to the wealthiest states in Nigeria. While governors and state politicians benefitted from these additional resources, the provision of public goods and the living conditions of the local population barely improved. ${ }^{57}$ In 2000, President Obasanjo responded to the demands for economic and social development in the region by establishing the Niger Delta Development Commission (NDDC). While the NDDC was well financed (4 billion dollars in 2007), it has been viewed as a tool for corruption and the embezzlement of funds in infrastructure projects. ${ }^{58}$

In the early 2000s, the Movement for the Emancipation of the Niger Delta (MEND) and the Niger Delta People's Volunteer Force (NDPVF) established themselves as the spearhead of the new violent struggle against the state and the oil companies. Both organizations claimed responsibility for various attacks on oil infrastructure and the kidnapping of oil workers in order to draw international attention to their grievances. ${ }^{59}$ In a number of attacks on pipelines and kidnappings in 2006, MEND achieved its goal of hitting the state by crippling the Nigerian oil output by around one third. ${ }^{60}$

The proposed motive-mechanism explains the onset of the violent insurgency. However, the change from a non-violent struggle to a violent insurgency brought along new aspects where financial opportunities and violent rent-seeking among insurgents groups became increasingly central.

\section{Financial Opportunities: Oil Theft, Kidnapping, Security Contracts}

Apart from providing a motive, natural resources can provide financial opportunities to insurgents. Particularly in a weak state, the illegal access to resources can incentivize violent rent-seeking, regardless of a motive.

In the Niger Delta, there are various methods to benefit from oil operations. Groups can sabotage pipelines to steal oil or kidnap expatriate oil workers for ransom. Other methods include demanding financial compensation for oil spills (whether due to operational failure or deliberate sabotage) and so-called security contracts between oil companies and armed groups.

Due to the physical absence of state institutions in large areas of the Niger Delta, violent attacks by insurgent groups in the beginning of the 2000s were largely directed at oil companies, who were seen as accomplices of the Nigerian state. ${ }^{61}$ The kidnapping of oil workers was initially a tool to force oil companies to leave the area. The oil companies did not leave, but adapted their security strategy. In order to reduce the risks of kidnapping, oil workers were moved to gated communities, so-called "life camps", and were transported only with armed escorts by the army or contracted armed groups. Through these contracted escort services, armed groups all over the Niger Delta benefitted financially. ${ }^{62}$ 
When armed groups' leaders realized that their violent actions were also a lucrative endeavor, pipeline sabotage and kidnapping developed into a more organized business. For instance, oil companies, above all Shell, provided "security contracts" to sabotaging groups to prevent further vandalization of its operating infrastructure. While a security contract discouraged the contracted group, it encouraged the emergence of other groups to compete for security contracts and by extension incentivized violence. ${ }^{63}$

MEND, NDPVF, and other armed groups did not operate in a political void. Since the return to democratic rule in 1999, state and local politicians used such groups particularly during the elections in 1999 and 2003 to fight political competitors and rally support. With the connection to and the patronage of politicians, militant groups were an integral chain link in the large-scale oil theft (known as "bunkering"), which has become a massive shadow industry worth billions of dollars annually. ${ }^{64}$ While sabotaging oil pipelines was a tool to hit the Nigerian State in the beginning of the struggle, it increasingly changed into a criminal syndicate where Niger Delta militants, politicians and businessmen from all over Nigeria, the army, and international actors cooperated to steal oil. ${ }^{65} \mathrm{~A}$ similar configuration of actors are viewed to be responsible for the emergence of piracy in the Gulf of Guinea. ${ }^{66}$

During field research in the Niger Delta, we found that pipelines in the riverine creek areas were vulnerable for oil bunkering. However, those areas without waterways were not affected by oil bunkering. It therefore makes a substantial difference under what conditions the stolen oil can be transported. ${ }^{67}$

To summarize, plenty of financial opportunities arose from oil operations in the Niger Delta. The empirical evidence lends substantive support to the opportunity mechanism. It does, however, also expose the limits of the argument, because these opportunities not only attracted insurgents, but also corrupted state institutions such as the army and the political elite. ${ }^{68}$ This cooperative system of plunder between insurgents and state actors may even have stabilized the region.

\section{The Nigerian Way: Political Inclusion Through Federal Disaggregation}

The second argument we set out to test is whether the political representation of local groups is associated with political violence. Following Cederman et al., ${ }^{69}$ we theorize that political representation has an inverse effect on political violence, because policies addressing local grievances become more credible by having a representative being involved.

We start by reflecting on the function of the federal system in Nigeria in particular its frequent extension to address pressing demands for more representation among local groups. We then proceed to the particularities of grievances in the Niger Delta in addition to the Middle Belt and Northeastern Nigeria.

With its nearly 180 million inhabitants and more than 250 ethnic groups, ${ }^{70}$ Nigeria is a particularly large and culturally diverse country. The three largest ethnic groups, the Hausa-Fulani, the Yoruba, and the Igbo, make up around 6070 percent of the population. These groups have dominated the political and economic sphere in Nigeria since independence from Britain in 1960. Ethnic minority groups have ever since struggled against economic, political, and deprivation marginalization. To accommodate local minorities, at least in theory, Nigeria has adopted a federal system with three tiers of governance: on the top, the federation, comprised by 36 states (plus Abuja, the federal capital territory) and 774 LGAs. While the institutional 
structure would allow decentralized political decision-making and implementation of public services, the federal and the state governments have retained a thorough grip on power and resources, leaving LGAs largely as mere "ghost cabinets.","1

The design, modification, and extension of the federal system have been a theater of power struggles among Nigerian politicians. At the time of independence Nigeria was divided into three regions, which were further divided in several stages, reaching 36 states in 1996. These changes have most often been initiated by smaller ethnic minority groups which felt that their interests were poorly represented by their respective state governments. ${ }^{72}$

With the creation of new states and LGAs, the Nigerian state responded to political demands of ethnic minorities for better territorial representation and access to oil rents. ${ }^{73}$

\section{Addressing Ijaw Demands for More Representation: Appointing Goodluck Jonathan as Vice-President}

The inauguration of late President Yar'Adua in May 2007 raised hope for a more constructive approach to resolve the Niger Delta conflict. Appointing Goodluck Jonathan, an ethnic Ijaw and serving governor of oil-rich Bayelsa State, as his vicepresidential running mate had been a move to respond to demands of Ijaw for more representation in the government. ${ }^{74}$ After President Yar'Adua passed away in 2010, Goodluck Jonathan was constitutionally appointed to serve as the President of Nigeria. Tentative results from a survey we conducted in three communities in Rivers State suggest that it is "very important" (the highest rating) to have "someone" from the Niger Delta as President of Nigeria, regardless of whether respondents were Ijaw. Further, the release of several high-ranking Ijaw leaders from prison and increasing dialogue with militants were perceived as a fortunate turn in the government's approach.

To respond to the increasing violence in the Niger Delta, in 2009 the government offered an amnesty program to all Niger Delta militants. The amnesty granted freedom from prosecution to all militants who surrendered. ${ }^{75}$ Around 20,000 militants surrendered, each thereafter receiving 420 dollars per month. Some argue that the amnesty program was successful in attracting former militants by providing comparably large cash incentives, but that it failed to address the root causes of the conflict. ${ }^{76}$

While attacks on oil infrastructure and violent events substantially dropped since the amnesty was launched, organized oil bunkering, illegal oil refining, kidnapping, and turf wars between armed groups continued to flourish. ${ }^{77}$

\section{Religious and Ethnic Tensions and Political Violence in Northern Nigeria}

Our study focuses on violence related to the political economy of oil, bringing into focus the conflicts in and around the Niger Delta region. However, other conflicts have played an increasingly important role in Nigeria. For example, tensions and clashes between Muslim and Christian groups are particularly salient in Northern Nigeria and the Middle Belt. ${ }^{78}$

While religion is not the only factor, many of the conflicts in the area have a specific religious element that is regarded as crucial to legitimize violence. There is an overlap with other conflict dimensions over lifestyles (herders vs. farmers), 
socio-economic disparities, and land claims (indigenes vs. settlers) that have deepened religious cleavages. ${ }^{79}$

In Kaduna for instance, violence in the beginning of the 2000s between the Muslim Hausa majority and around 30 Christian minority groups has been attributed to economic disparities. Horizontal inequalities, grievances, and theological disagreements between Christians and Muslims have spurred large-scale riots, leaving thousands dead. The recurring violence keeps reinforcing religious cleavages. ${ }^{80}$ Similar conflicts have taken place in Jos and its hinterlands in Plateau state. ${ }^{81}$

Historically, Northern Nigeria has always resisted the secular worldviews of the South. The reintroduction of Sharia law after Sani Abacha's military rule (1993 1998) and the return to democratic rule in 1999 was seen as a possibility of moral and political renewal within the north. The dominant perception among Muslims that secular state institutions and a Christian President are a primal cause of political corruption and moral decay has aggravated relations with their Christian neighbors. $^{82}$

Simultaneously, for many Christians the reintroduction of Sharia law around 1999 caused insecurity about their position in these states. ${ }^{83}$ Nigerian Christians themselves cultivated a feeling of threat through the Muslim majority in the area. Similarly to Muslim organizations, Christian groups started to take a stronger political role in the area. Increasing attempts by Pentecostal leaders to attract followers and the monitoring of religious balance in government bodies had strong impacts on the creation of religious cleavages. This increasing level of polarization on both sides has frequently sparked violence. ${ }^{84}$ Besides the religious and ethnic attributes, the most fundamental underlying condition under which violence frequently erupts is widespread poverty and a lack of job opportunities, particularly for young people.

In recent years the Islamist organization Boko Haram has claimed responsibility for an increasing number of attacks in the North, in particular the Northeastern part of Nigeria, but also the capital Abuja. Boko Haram's home base is in the Northeastern state of Borno. It builds on a general atmosphere of resistance towards secularism that has existed in Northern Nigeria at least since the transition to democracy in 1999. The attraction of Boko Haram's world view for followers remains unclear. It seems plausible that the group's appeal stems from a general discontent with the Nigerian state and its corrupt practices as well as the dire economic situation and high levels of unemployment in the area. ${ }^{85}$ Although this goes beyond the scope of this paper, the civilian government appears to be increasingly powerless to adequately respond and manage the crisis with Boko Haram.

Neither in the case of the Middle Belt nor Boko Haram do we find indication that local groups simply demand more representation at the national level. In the Middle Belt, violence is associated with local cleavages. In Northeastern Nigeria, Boko Haram sees its fight as a fight against moral decay and corruption of the state.

\section{Discussion}

How do these qualitative accounts stand to the proposed theoretical framework? First, there is considerable support for the "resource curse" argument. High-profile corruption and embezzlement as well as poor governance all fueled by oil rents and lack of development and job opportunities provide the conditions for social and political conflict. Second, there is evidence that at least the beginning of the Niger Delta struggle was motivated by unaddressed grievances and state repression. 
Qualitative accounts lend substantial support to the argument that the Nigerian state set the spiral of violence in motion by preemptively repressing non-violent movements in the Niger Delta in order to keep public order and continue oil extraction. This state reaction sent strong signals to social movements and was largely interpreted as underlining that non-violent means were an inappropriate strategy to engage the government in a constructive dialogue to address local grievances. Third, we find strong support for the opportunity argument. During the transformation from a non-violent to a violent struggle, the original motives blurred into increasingly opportunistic behavior. The empirical evidence does, however, also expose the limits of the opportunity argument. In the case of the Niger Delta, not only insurgents, but also politicians, the army, and others were involved in opportunistic oil theft.

The claim that political inclusion reduces the risk of political conflict is in general supported by empirical evidence. For one, Nigeria was quite liberal in creating new states and thereby granting local groups a degree of autonomy as well as political participation.

Also, in the case of the Niger Delta conflict, the accession to power of Goodluck Jonathan as Vice-President sent strong signals to the Delta region, even if it had little impact on the living conditions of the people. Additionally, the amnesty program had probably the largest effect on decreasing violence.

The violent conflict in the Middle Belt and Northern Nigeria features a very unique set of multiple cleavages (e.g., indigenes vs. settlers, Christian vs. Muslims, secular institutions vs. Sharia). Balanced political power at the state level between the conflicting groups is important to reduce violence. Further, ambitious development initiatives in the North would help to address local grievances arising from poverty, lack of employment, and poor public goods provision.

In sum, the theoretical framework provides substantial explanatory power to understand Nigerian politics and conflict.

\section{Conclusion}

This article set out to test two prominent arguments in the civil war literature. First, that oil production promotes social and political conflict in the context of a weak state through three causal mechanisms (resource curse, motive, and opportunity). And second, that unaddressed grievances and political exclusion are predictors of conflict.

We employ a mixed-methods design to test these arguments, combining quantitative and qualitative evidence. Using novel data on the geolocation of oil infrastructure, we find that LGAs the lowest political entity in Nigeria with more oil production experience more violence. With regard to the effect of political representation, we find that including local minorities has a pacifying effect. Our results are robust across various models, data, and specifications. We add a qualitative test and find overall support for the proposed causal mechanisms.

Although our study was designed as a mere test of existing arguments, our theoretical contribution is twofold. First we combine two theoretical arguments in one analysis and show that both are significantly associated with political violence. Second, we refine existing theory. In particular, we show that the opportunity mechanism does attract both non-state armed groups as well as state actors and that cooperation among them had even stabilized the security context in the region. 
Empirically, we enrich the existing discourse on Nigeria with a broader picture on the role of oil and political inclusion.

\section{Acknowledgments}

We are grateful for extensive comments from Matthias Basedau, Annegret Mähler, Alexander De Juan, and Johannes Vüllers, as well as two helpful anonymous reviewers.

\section{Funding}

This project has been financed by the German Science Foundation.

\section{Supplemental Material}

The supplementary appendix can be found online at http://dx.doi.org/10.1080/ 09546553.2014.962021.

\section{Notes}

1. Lars Erik Cederman, Andreas Wimmer, and Brian Min, "Why Do Ethnic Groups Rebel? New Data and Analysis," World Politics 62, no. 1 (2010): 87, doi:10.1017/ S0043887109990219.

2. Michael L. Ross, The Politics of the Resource Curse: A Review, SSRN Scholarly Paper ID 2342668 (Rochester, NY: Social Science Research Network, 2013), http://papers. ssrn.com/abstract $=2342668$.

3. Ted Robert Gurr, Why Men Rebel (Princeton: Princeton University Press, 1970).

4. Paul Collier and Anke Hoeffler, "Greed and Grievance in Civil War," Oxford Economic Papers 56, no. 4 (2004): 563 595, doi:10.1093/oep/gpf064; James D. Fearon and David D. Laitin, "Ethnicity, Insurgency, and Civil War," American Political Science Review 97, no. 1 (2003): 75 90, doi:10.1017/S0003055403000534.

5. An exception to this is a survey among Niger Delta youths and their probability of joining an armed group (Aderoju Oyefusi, "Oil and the Probability of Rebel Participation Among Youths in the Niger Delta of Nigeria," Journal of Peace Research 45, no. 4 (2008): 539 555, doi:10.1177/0022343308091360; Aderoju Oyefusi, "Oil, Youths, and Civil Unrest in Nigeria's Delta: The Role of Schooling, Educational Attainments, Earnings, and Unemployment," Conflict Management and Peace Science 27, no. 4 (2010): 326 346, doi:10.1177/0738894210374399.

6. E.g., Jedrzej George Frynas, "Corporate and State Responses to Anti Oil Protests in the Niger Delta," African Affairs 100, no. 398 (2001): 27 54, doi:10.1093/afraf/100.398.27; Jennifer Hazen and Jonas Horner, Small Arms, Armed Violence, and Insecurity in Nigeria: The Niger Delta in Perspective (Geneva: Small Arms Survey, 2007); Ukoha Ukiwo, "From 'Pirates' to 'Militants': A Historical Perspective on Anti State and Anti Oil Company Mobili zation among the Ijaw of Warri, Western Niger Delta," African Affairs 106, no. 425 (2007): 587 610, doi:10.1093/afraf/adm057; Michael Watts, "Resource Curse? Governmentality, Oil and Power in the Niger Delta, Nigeria," Geopolitics 9, no. 1 (2004): 50 80, doi:10.1080/ 14650040412331307832 .

7. The federal system in Nigeria is composed of the federation as top tier, the 36 states as second tier, and the LGAs as third tier.

8. Philippe Le Billon, "The Political Ecology of War: Natural Resources and Armed Conflicts," Political Geography 20, no. 5 (2001): 561 584; Philippe Le Billon, "Diamond Wars? Conflict Diamonds and Geographies of Resource Wars," Annals of the Association of American Geographers 98, no. 2 (2008): 345 372, doi:10.1080/00045600801922422; Michael L. Ross, "How Do Natural Resources Influence Civil War? Evidence from Thirteen Cases," International Organization 58, no. 1 (2004): 35 67, doi:10.1017/S002081830458102X; 
Michael L. Ross, "What Do We Know about Natural Resources and Civil War?," Journal of Peace Research 41, no. 3 (2004): 337 356, doi:10.1177/0022343304043773.

9. Le Billon, "Diamond Wars?" (see note 8 above), 347 349. We use the term "resource curse" throughout this paper in a broader sense including the weak state mechanism, Dutch Disease, government's revenue volatility, and the economic resource curse.

10. Silje Aslaksen, "Oil and Democracy: More than a Cross Country Correlation?," Journal of Peace Research 47, no. 4 (2010): 421 431, doi:10.1177/0022343310368348; Hazem Beblawi, "The Rentier State in the Arab World," in Giacomo Luciani, ed., The Arab State (University of California Press, 1990), 85 98; Halvor Mehlum, Karl Moene, and Ragnar Torvik, "Institutions and the Resource Curse," The Economic Journal 116, no. 508 (2006): 1 20, doi:10.1111/j.1468 0297.2006.01045.x; Kevin K. Tsui, "More Oil, Less Democracy: Evidence from Worldwide Crude Oil Discoveries," The Economic Journal 121, no. 551 (2011): 89 115, doi:10.1111/j.1468 0297.2009.02327.x.

11. Le Billon, "Diamond Wars?" (see note 8 above); Ross, "How Do Natural Resources Influence Civil War? (see note 8 above).

12. Ross, "How Do Natural Resources Influence Civil War? (see note 8 above)

13. Richard Auty, Resource Abundance and Economic Development (Oxford University Press, 2001); Le Billon, "The Political Ecology of War" (see note 8 above).

14. Fearon and Laitin, "Ethnicity, Insurgency, and Civil War" (see note 4 above); James D. Fearon, "Primary Commodity Exports and Civil War," Journal of Conflict Resolution 49, no. 4 (2005): 483 507, doi:10.1177/0022002705277544; Macartan Humphreys, "Natural Resources, Conflict, and Conflict Resolution," Journal of Conflict Resolution 49, no. 4 (2005): 508 537, doi:10.1177/0022002705277545; Päivi Lujala, Nils Petter Gleditsch, and Elisabeth Gilmore, "A Diamond Curse?: Civil War and a Lootable Resource," Journal of Conflict Resolution 49, no. 4 (2005): 538 562, doi:10.1177/0022002705277548.

15. Päivi Lujala, Jan Ketil Rod, and Nadja Thieme, "Fighting over Oil: Introducing a New Dataset," Conflict Management and Peace Science 24, no. 3 (2007): 239256 , doi:10.1080/07388940701468526; Indra De Soysa and Eric Neumayer, "Resource Wealth and the Risk of Civil War Onset: Results from a New Dataset of Natural Resource Rents, 1970 1999," Conflict Management and Peace Science 24, no. 3 (2007): 201 218, doi:10.1080/ 07388940701468468.

16. Päivi Lujala, "Deadly Combat over Natural Resources: Gems, Petroleum, Drugs, and the Severity of Armed Civil Conflict," Journal of Conflict Resolution 53, no. 1 (2009): 50 71, doi:10.1177/0022002708327644; Jason Sorens, "Mineral Production, Territory, and Ethnic Rebellion: The Role of Rebel Constituencies," Journal of Peace Research 48, no. 5 (2011): 571 585, doi:10.1177/0022343311411743.

17. Matthias Basedau and Jann Lay, "Resource Curse or Rentier Peace? The Ambiguous Effects of Oil Wealth and Oil Dependence on Violent Conflict," Journal of Peace Research 46, no. 6 (2009): 757 776, doi:10.1177/0022343309340500.

18. Anca M. Cotet and Kevin K Tsui, "Oil and Conflict: What Does the Cross Country Evidence Really Show?," American Economic Journal: Macroeconomics 5, no. 1 (2013): 49 80, doi:10.1257/mac.5.1.49.

19. Michael L. Ross, The Politics of the Resource Curse: A Review, SSRN Scholarly Paper ID 2342668 (Rochester, NY: Social Science Research Network, 2013), http://papers ssrn.com/abstract $=2342668$.

20. Gurr, Why Men Rebel (see note 3 above).

21. Christopher Blattman and Edward Miguel, "Civil War," Journal of Economic Literature 48, no. 1 (2010): 3 57, doi:10.1257/jel.48.1.3. The prevalent constructivist concept understands ethnicity as a set of visible identity features, such as language, region, color, etc., that serve to recognize a kin or non kin (see Donald Horowitz, Ethnic Groups in Conflict [Berkeley: University of California Press, 1985], 53). Social identity theory (Henri Tajfel and John C. Turner, "An Integrative Theory of Intergroup Conflict," in W. G. Austin and S. Worchel, eds., The Social Psychology of Intergroup Relations [Monterey, CA: Brooks/Cole, 1979], 33 47) provides the basis for this concept and suggests that people are able to identify with others even over petty commonalities (also known as the minimal group paradigm).

22. Mark Lichbach, The Rebel's Dilemma (Ann Arbor: University of Michigan Press, 1995).

23. Frances Stewart, Horizontal Inequalities and Conflict: Understanding Group Violence in Multiethnic Societies (Basingstoke, England: Palgrave Macmillan, 2008); Gudrun Østby, 
"Polarization, Horizontal Inequalities and Violent Civil Conflict," Journal of Peace Research 45, no. 2 (2008): 143 162, doi:10.1177/0022343307087169; Lars Erik Cederman, Nils B. Weidmann, and Kristian Skrede Gleditsch, "Horizontal Inequalities and Ethnonationalist Civil War: A Global Comparison," American Political Science Review 105, no. 3 (2011): 478 495, doi:10.1017/S0003055411000207.

24. Cederman, Wimmer, and Min, "Why Do Ethnic Groups Rebel?" (see note 1 above).

25. We will describe the scope conditions of the Nigerian context later in the qualitative section in order to provide evidence for the weak state mechanism. However, given that national institutional quality would not vary within Nigeria, we exclude it from the hypotheses and treat it as a scope condition.

26. Note that we are unable to distinguish between motive and opportunity channels in our statistical analysis, since observable implications are the same. In addition, it is important to recognize the literature on natural resources and violence has largely focused on the motiv ation of rebels to engage in violence against the state, but comparatively less attention has been paid to the state's incentives for engaging in repression to secure natural resource rents. The presence of oil infrastructure might provide incentives for government actors to use more violent forms of repression and also produce an empirical association between oil infrastruc ture and violence.

27. Cederman, Wimmer, and Min, "Why Do Ethnic Groups Rebel?" (see note 1 above).

28. Evan S. Lieberman, "Nested Analysis as a Mixed Method Strategy for Comparative Research," American Political Science Review 99, no. 3 (2005): 435 452, doi:10.1017/ S0003055405051762; Alexander L. George and Andrew Bennett, Case Studies and Theory Development in the Social Sciences, BCSIA Studies in International Security (Cambridge, MA: MIT Press, 2005).

29. The events recorded in the database are accompanied by detailed information and the identity of participants, time and location of the event, cause of the event, and further infor mation. We tried to be inclusive in the generation of our aggregate event count and opted to include all events, except for incidents labeled as car accidents. This means our event count variable contains instances of rebel groups fighting government forces, clashes between ethnic groups, violence by criminal gangs, violence between private security forces and local groups, as well as mob lynchings motivated by claims of sorcery and black magic.

30. The data collected by Nigeria Watch only record cases with at least one casualty. Therefore, certain instances of oil related conflict such as pipeline sabotage and kidnappings without casualties are not recorded.

31. Lujala, Rod, and Thieme, "Fighting over Oil" (see note 15 above).

32. While both measures provide more fine grained data on the physical infrastructure asso ciated with oil extraction, we lack reliable information on the volume of oil production. Infor mation on oil production is closely guarded by the Nigerian Ministry of Petroleum Resources.

33. Ilia Rainer and and Francesco Trebbi, New Tools for the Analysis of Political Power in Africa, Working Paper 18424 (Cambridge, MA: National Bureau of Economic Research, 2012), http://www.nber.org/papers/w18424. Refer to the online appendix (see "Supplemental" section above for details) to get more detail on the coding scheme and the main linguistic group categories and its subgroups.

34. See, e.g., Rotimi T. Suberu, Federalism and Ethnic Conflict in Nigeria (Washington, DC: U.S. Institute of Peace Press, 2001), chap. 5; Eghosa Osaghae, "Managing Multiple Minority Problems in a Divided Society: The Nigerian Experience," The Journal of Modern African Studies 36, no. 1 (1998): 124.

35. Ben Naanen, "Oil Producing Minorities and the Restructuring of Nigerian Federal ism: The Case of the Ogoni People," The Journal of Commonwealth \& Comparative Politics 33, no. 1 (1995): 46 78, doi:10.1080/14662049508447695; Eghosa Osaghae, "Ethnic Minorities and Federalism in Nigeria," African Affairs 90, no. 359 (1991): 237258.

36. This variable is based on ethnic settlement maps provided by Nigeria's Statistical Bureau, since the population census does not contain any information on ethnicity.

37. OAGF, Office of the Accountant General of the Federation, A Compendium of Federation Account Revenue Allocation to the Federal, States and Local Governments in Nigeria, Vol. 1: 1999 2003; Vol. 2: 20042008 (Abuja: Federal Ministry of Finance, 2008).

38. Authors' interviews with government officials and NGO representatives, Abuja, Lagos, Port Harcourt, February 2013. 
39. We follow established regional divisions: North Central, Northeastern, Northwest ern, Southeastern, South South, and Southwestern. Adding regional dummies also controls for unobserved variables (like religious polarization) that might affect our analysis.

40. Results are shown in the Appendix, available online.

41. Based on Model (1) in Table 1. We set all control variables at their respective means, medians, or modes. Simulations were performed using CLARIFY in STATA.

42. In the total sample our ethnic inclusion measure varies from 0 to 0.61 with a standard deviation of 0.15 , while in the Niger Delta the measure ranges from 0 to 0.30 with a standard deviation of 0.08 .

43. Clionadh Raleigh, Andrew Linke, Håvard Hegre, and Joakim Karlsen, "Introducing ACLED: An Armed Conflict Location and Event Dataset Special Data Feature," Journal of Peace Research 47, no. 5 (2010): 651 660, doi:10.1177/0022343310378914.

44. Ralph Sundberg and Erik Melander, "Introducing the UCDP Georeferenced Event Dataset," Journal of Peace Research 50, no. 4 (2013): 523 532, doi:10.1177/ 0022343313484347.

45. George and Bennett, Case Studies and Theory Development in the Social Sciences (see note 28 above).

46. A. Gboyega, T. Soreide, T. Le, and G. P. Shukla, "Political Economy of the Petroleum Sector in Nigeria," World Bank Policy Research Working Paper Series, Vol. 1, Policy Research working paper, no. WPS 5779, 2011, 7, http://papers.ssrn.com/sol3/papers. cfm?abstract id=1916541.

47. Authors' interview with Prof. Ekekwe, University of Port Harcourt, November 12, 2013.

48. Hazen and Horner, Small Arms, Armed Violence, and Insecurity in Nigeria (see note 6 above), 76

49. UNDP, International Human Development Indicators Nigeria, 2013, http://hdrstats. undp.org/en/countries/profiles/NGA.html.

50. Authors' interview with Celestine AkpoBari, Head of Social Action, Port Harcourt, November 11, 2013.

51. Daniel Jordan Smith, A Culture of Corruption: Everyday Deception and Popular Discontent in Nigeria (Princeton: Princeton University Press, 2007).

52. Authors' interview with Matt Halsted, Chief Financial Officer of Stakeholder Democracy Network, Port Harcourt, November 10, 2013.

53. The Niger Delta typically refers to the nine oil producing states in Nigeria's south east: Abia, Akwa Ibom, Bayelsa, Cross River, Delta, Edo, Imo, Ondo, and Rivers. The majority of Nigeria's oil output is extracted in Bayelsa, Delta, and Rivers.

54. UNEP, United Nations Environment Programme, Environmental Assessment of Ogoniland (United Nations Environment Programme, 2011), http://www.unep.org/disasters andconflicts/CountryOperations/Nigeria/EnvironmentalAssessmentofOgonilandreport/ tabid/54419/Default.aspx.

55. Ike Okonta and Douglas Oronto, Where Vultures Feast: Shell, Human Rights and Oil in the Nigerian Delta (New York: Verso, 2013), 116 126; UNEP, Environmental Assessment of Ogoniland (see note 54 above), chap. 1.

56. Ukoha Ukiwo, "The Nigerian State, Oil and the Niger Delta Crisis," in Cyril Obi and Siri Aas Rustad, eds., Oil and Insurgency in the Niger Delta: Managing the Complex Politics of Petroviolence (London: Zed Books, 2011), 1727.

57. Smith, A Culture of Corruption (see note 51 above); Ukiwo, "The Nigerian State, Oil and the Niger Delta Crisis" (see note 56 above). The allocation of oil revenues between the federal government and the 36 state governments is regulated in a derivation formula. Basi cally, all of Nigeria's oil revenues first go into the federation account, which is administered by the Ministry of Finance at the federal level. From the total, a share is deducted which is allocated to the nine oil producing states. Since 2000, each oil producing state receives 13 per cent of its generated oil revenues (formerly in 1984 only 1.5 percent, in 1992 only 3 percent). The remaining sum is then split between the federal government and the 36 federal states (both oil producers and non producers) according to geographic, socio demographic, and develop ment indicators (OAGF, A Compendium of Federation Account Revenue Allocation to the Federal, States and Local Governments in Nigeria [see note 37 above]).

58. Chris Newsom, Conflict in the Niger Delta: More than a Local Affair (Washington, DC: United States Institute of Peace, 2011), http://dspace.cigilibrary.org/jspui/handle/ 
123456789/31585; Michael Watts and Ibaba Samuel Ibaba, "Turbulent Oil: Conflict and Insecurity in the Niger Delta," African Security 4, no. 1 (2011): 1 19, doi:10.1080/19392206. 2011.563181.

59. Elias Courson, "MEND: Political Marginalization, Repression, and Petro Insurgency in the Niger Delta," African Security 4, no. 1 (2011): 20 43, doi:10.1080/19392206. 2011.551060.

60. Michael Watts, "Petro Insurgency or Criminal Syndicate? Conflict and Violence in the Niger Delta," Review of African Political Economy 34, no. 114 (2007): 637 660, doi:10.1080/03056240701819517.

61. O. Owolabi and I. Okwechime, "Oil and Security in Nigeria: The Niger Delta Crisis," Africa Development 32, no. 1 (2007), doi:10.4314/ad.v32i1.57152; Okonta and Douglas, Where Vultures Feast (see note 55 above).

62. Platform, Counting the Cost: Corporations and Human Rights Abuses in the Niger Delta (London: Platform, 2011), http://platformlondon.org/nigeria/Counting the Cost.pdf. Authors' interviews and observations in Port Harcourt and surrounding areas, November 2013.

63. Platform, Counting the Cost (see note 62 above); Stakeholder Democracy Network, Does Violence Pay? Review of Niger Delta Community Perceptions on Conflict, Militancy and Change (Port Harcourt: SDN, 2013).

64. Gboyega et al., "Political Economy of the Petroleum Sector in Nigeria" (see note 46 above); Christina Katsouris and Aaron Sayne, Nigeria's Criminal Crude: International Options to Combat the Export of Stolen Oil (London: Chatham House, 2013), http:/ /www.chathamhouse. org/publications/papers/view/194254; Smith, A Culture of Corruption (see note 51 above); Ukiwo, "From 'Pirates' to 'Militants"' (see note 6 above).

65. Charles Gore and David Pratten, "The Politics of Plunder: The Rhetorics of Order and Disorder in Southern Nigeria," African Affairs 102, no. 407 (2003): 211 240, doi:10.1093/ afraf/adg002; Watts, "Petro Insurgency or Criminal Syndicate?" (see note 60 above).

66. Godwin Onuoha, "Energy and Security in the Gulf of Guinea: A Nigerian Perspec tive," South African Journal of International Affairs 16, no. 2 (2009): 245 264, doi:10.1080/ 10220460903269008.

67. Authors' interviews and observations during field research in Akapuka, Okrika, and Bodo, November 2013.

68. Watts, "Petro Insurgency or Criminal Syndicate?" (see note 60 above); Gore and Pratten, "The Politics of Plunder" (see note 65 above).

69. Cederman et al., "Why Do Ethnic Groups Rebel?" (see note 1 above).

70. Central Intelligence Agency (CIA), The World Factbook Nigeria, 2014, https:// www.cia.gov/library/publications/the world factbook/geos/ni.html.

71. Authors' interview with government official, Abuja, January 31, 2013. United Nations Development Programme (Abuja, Nigeria: UNDP), Human Development Report Nigeria 2008 2009, 2009, 103; Suberu, Federalism and Ethnic Conflict in Nigeria (see note 34 above), 173.

72. Suberu, Federalism and Ethnic Conflict in Nigeria (see note 34 above).

73. Gboyega et al., "Political Economy of the Petroleum Sector in Nigeria" (see note 46 above); Watts, "Petro Insurgency or Criminal Syndicate?" (see note 60 above).

74. International Crisis Group, Nigeria: Ending Unrest in the Niger Delta (Abuja: Author, 2007).

75. Mark Davidheiser and Kialee Nyiayaana, "Demobilization or Remobilization? The Amnesty Program and the Search for Peace in the Niger Delta," African Security 4, no. 1 (2011): 44 64. doi:10.1080/19392206.2011.551063.

76. Courson, "MEND: Political Marginalization, Repression, and Petro Insurgency in the Niger Delta" (see note 59 above); Davidheiser and Nyiayaana, "Demobilization or Remobilization?" (see note 75 above).

77. Newsom, Conflict in the Niger Delta (see note 58 above).

78. Northern Nigeria refers to twelve northern states (Bauchi, Borno, Gombe, Jigawa, Kaduna, Kano, Katsina, Kebbi, Niger, Sokoto, Yobe, and Zamfara) that reintroduced Sharia law in 1999. The Middle Belt includes the states of Kwara, Kogi, Benue, Plateau, and Nasarawa (International Crisis Group, Northern Nigeria: Background to Conflict [Abuja: Author, 2010]). 
79. International Crisis Group, Curbing Violence in Nigeria (I): The Jos Crisis, Africa Report No. 196.2012 (Abuja: Author, 2012).

80. Africa Report, Nigeria: Fixing the Middle Belt, 2010, http://www.theafricareport. com/News Analysis/nigeria fixing the middle belt.html.

81. Aaron Sayne, Rethinking Nigeria's Indigene Settler Conflicts (U.S. Institute of Peace, 2012), http://kms1.isn.ethz.ch/serviceengine/Files/ISN/150830/ipublicationdocument singledocument/b91e285e 2e4c 4a4d 98d9 ff8c0c382104/en/SR311.pdf; International Crisis Group, Curbing Violence in Nigeria (I): The Jos Crisis (see note 79 above).

82. International Crisis Group, Northern Nigeria (see note 78 above).

83. Under British colonial rule Sharia law was reduced in its scope and finally banned as not being compatible within a multi ethnic and multi religious society (International Crisis Group, Northern Nigeria [see note 78 above], 15).

84. International Crisis Group, Northern Nigeria (see note 78 above).

85. Iro Aghedo and Oarhe Osumah, "The Boko Haram Uprising: How Should Nigeria Respond?," Third World Quarterly 33, no. 5 (2012): 853 869, doi:10.1080/01436597.2012. 674701 . 